\title{
Towards Lexicographic Description of Idioms \\ in the English Language: \\ Comparative Analysis
}

\author{
Yulia S. Perevezentseva* \\ Nizhny Novgorod State Technical University n.a. R.E. Alekseev \\ 24 Minin Str., Nizhny Novgorod, 603950, Russia
}

Received 27.02.2015, received in revised form 11.09.2015, accepted 07.11.2015

The aim of the article is to compare two practices of lexicographic description of idioms: British and American. Modern and authority American and British dictionaries of idioms become the focus of interest. The subject matter is an entry, and the object of study is its significative and denotative, connotative and additional components. The study reveals merits and otherwise, perspectives of the compared lexicographic practices.

Keywords: idiom, dictionary, lexicographic description, British and American dictionaries of idioms.

DOI: 10.17516/1997-1370-2015-8-11-2572-2581.

Research area: pedagogy, philology .

\section{Introduction}

Being international the English language arouses a great interest in the contemporary world. In this regard, among English learners there is a tendency to free language, a desire to make their oral and written language more colorful, fascinating and to understand an underlying subtext in literature. It is no secret that idioms create the main difficulties in the study of the language. Not living in the target language, the images using English-speaking population seem to be very strange. As a result, one of the main problems learners have with idioms is that it is often impossible to guess the meaning of an idiom from the words it contains.
Comprehensive studies on the nature of idioms and the methods of their investigation have had a significant impact on the development and further improvement of phraseography. The main element of idioms dictionary, like any other, is an entry. It concentrates all information about an interpret unit and reflects the basic principles of one or the other of the two lexicographical publications.

The form of an entry is quite straightforward, consisting of entry head, definition, comments (if any), and examples. Each component of an entry is paid enough attention in modern lexicography. Linguists focus on labels (S.K. Bashieva (1998), V.I. Telia (1996), D.A. Zhorzholiani (1987)),

(C) Siberian Federal University. All rights reserved

* Corresponding author E-mail address: khokhlovaj@mail.ru 
the principles of idiom interpretation (A.N. Baranov and D.O. Dobrovolskii (1998), I.A. Sternin and T.A. Chiubur (2006)), its variations (I.A. Sternin (1986)) and choice of examples (L.V. Minaeva (1986), M.R. L'vov (2000)). L.P. Stupin (1985), A.V. Kunin (1996), A. Makkai (1972), R. Moon (1998) made indispensable contribution to the study of general and particular problems of English theoretical and applied lexicography. The writings of modern scholars - Yu.A. Ermolaeva (1990), A.R. Ayupova (2009) - revived a former interest to the problem of lexicographic description form the basis of the article. The scientists analyze entries for fixed phrases (FP further). Comparing their researches, we note that Y. A. Ermolaeva analyzes an entry by studying its components (definition, gloss and examples), whereas in contrast, R.A. Ayupova highlights different meaning components of FP and associates them with the components of the entry. In our opinion, the pattern of lexicographic description of R.A. Ayupova is more comprehensive. Focus on the pattern in more detail.

\section{Theoretical framework}

R.A. Ayupova considers that usefulness of a lexicographical description must be estimated based on how full connotative, significative and denotative components of phraseological meaning are reflected in an entry, and how full additional components are presented in the entry. So, the scientist does entry research of FPs including idioms through analyzing of three elements: a significative and denotative macro-component of phraseological definition; a connotative macro-component of phraseological definition; additional components of an entry.

The first - the significative and denotative macro-component of phraseological definition relates to definitions. In spite of existing different classifications of vocabulary definitions in the scientific literature R.A. Ayupova believes that there are five characteristic types of vocabulary definitions:

- definition as a free phrase or a sentence (i.e. interpretation with a simple sentence);

- a combined type of definition (i.e. a definition may consists of several parts: "free phrase + fixed phrase (FP)", "lexical item + FP", "free phrase + lexical item + FP" and so on);

- definition as an expended sentence (i.e. interpretation with a complex sentence);

- definition as a lexical unit;

- definition as a synonym or an antonym.

At the same time, in the scientist's opinion, whichever definition is presented, it must be:

- clear, compact and precise;

- not interpreted by other FPs;

- created taking into account a category feature and a syntactic structure of a fixed unit. Other words, nominal FPs must be interpreted by nominal kennings; verb FPs - by verbs/verb phrases, etc. Thus, a definition within a microstructure of a phrase-book must show adequately all features of FPs which is put into dictionaries.

The connotative macro-component of phraseological definition is a reference to the analysis of special labels. R.A. Ayupova considers that all labels can be divided into seven categories. The first category involves the labels pointing at using FPs in a certain communicative area. It can be the following labels: literary, colloquial, subcolloquial, rude. The second category of labels points at communicative atmosphere in which the FP is used. It is so-called status labels: formal, informal, euphemism. The third category contains the labels informing of FP status 
within diachronic approach to the study of language. It is so-called temporal labels: archaic, old-fashioned, neologism, rare. The labels pointing at using of FPs in a certain field of human action or science belong to the forth category. The fifth category involves the labels that denote the function of FPs in a certain social sphere. It can be the following labels: slang, jargon, taboo, vulgar. The sixth category of labels classifies FPs on an area basis (regional labels). It is the following labels: American, Australian, Scottish, etc. Lastly the seventh category of labels points at the area in which an idiom has been used primarily. All these types of labels demonstrate a functional and stylistic aspect of FPs.

Also, in the scientist's opinion, there are socalled emotive and expressive labels in phrasebooks. The emotive labels show evaluation the FP: approbation, irony, disapproval, contempt, affection, etc. As a rule, expressiveness is a part of an entry and expresses through the following words: extremely, fully and etc.

Illustrative examples, etymological and culturological data, multiple meanings, variances of FPs, their valency (lexical, grammatical), optional words fall within additional components. R.A.Ayupova notes that there are several variances of FPs: graphical (Merrie (or Merry) England), lexical (the bowels of mercy/pity), morphological and syntax (have one's heart in one's mouth/one's heart sank into boots), grammatical (in the turn (turning) of a hand). Also to do entry research of a FP, it is necessary to pay attention whether there are optional units, lexical, grammatical valency in dictionaries. Any part of speech can be an optical unit. The unit is presented, as a rule, parenthetically, for example: at (long) last, (say) enough is enough. Lexical valency shows if the FP can be joined with some words or phrases. Grammatical valency appears when the FP can be joined with certain words groups.
If the three components are discussed, entry research may be considered fully. In our work entry research of an idiom will be realized according to the pattern suggested by R.A. Ayupova.

\section{Statement of the problem}

Taking into account uniqueness and originality of idioms, we believe that it is very interesting to study its lexicographic descriptions in a comparative manner. The importance of the research is caused by the possibility to study the different lexicographical traditions, to synthesis the common factors and practical results of lexicographic description of idioms and to estimate the achievements and the failures.

The guiding questions are as followers:

1. based on the analysis of the most authoritative dictionaries of idioms, to establish what types of definitions and how they are used for idioms semantization;

2. to analyze the labels;

3. to identify the most frequently used types of examples in the dictionaries;

4. to compare the principles of lexicographic descriptions in different dictionaries consistently.

The sources for our study are the most authoritative American and British dictionaries of idioms of the English language, namely: Dictionary of American Idioms (2005); The American Heritage Dictionary of Idioms (2003); Oxford Dictionary of Idioms (2004);

Cambridge International Dictionary of Idioms (2002). They all are modern (made after 2000 year), big (each contains several thousands of idiomatic expressions and phrases), monolingual (English), definition, alphabetized dictionaries. They are not only a collection of idioms but verbal collocations, clichés, explanations and sayings, similes and comparisons, common phrases, phrasal verbs. Thus, the used dictionaries are similar. 
Keeping in mind the lexis of the dictionaries, we can note dictionary makers to be far from the problem of defining idiom (S.Y. Chornobay, 2011; L. Grant, L. Bauer, 2004).

\section{Methods}

In the course of our research we use:

- the comparative method to study ways of lexicographic description in British English and American English;

- the descriptive method to definite features of lexicographic description in each of the above languages;

- the contextual method to analyze splitlevel idioms (morphological, grammatical, lexical and etc.);

- the quantification method to do quantitative research of interpretation ways of idioms.

\section{Discussion}

We start with studying of a significative and denotative component of an idiom in the chosen American and British dictionaries. According to R.

A. Ayupova, the characteristics of the component are formed on the basis of a definition analysis. In the Cambridge International Dictionary of Idioms we found definitions as free (simple) phrases or sentences, as expended (compound and complex) sentences as well as a combined type of definition (descriptive and etymological). In the Oxford Dictionary of Idioms entry heards are interpreted by using simple, compound and complex sentences as well as lexical units and cross-references. For idioms to be defined, expended and free sentences are mainly used in the American Heritage Dictionary of Idiom. The Dictionary of American Idioms uses the same ways of idiom interpretation as the Oxford Dictionary of Idioms. The quantitative analysis gives the possibility to correlate the types of definitions (see Table 1) and show what extent one or another type is widespread in the dictionaries under consideration.

According to the table much of definitions belong to the expended type, interpretations as free (simple) sentences come after them. Further the order is the following: lexical units, cross-references and, finally, a combined type of definitions. It should be noted that both the British and American dictionaries that are under investigation use variety of types of definitions.

Analyzing the components of the definitions, firstly, it was notable that definitions contain a specific part separated with the mark "hand"

Table 1

\begin{tabular}{|l|c|c|c|c|}
\hline \multicolumn{1}{|c|}{ Type of definition } & $\begin{array}{c}\text { Dictionary } \\
\text { of American Idioms }\end{array}$ & $\begin{array}{c}\text { The American } \\
\text { Heritage Dictionary } \\
\text { of Idioms }\end{array}$ & $\begin{array}{c}\text { Oxford Dictionary } \\
\text { of Idioms }\end{array}$ & $\begin{array}{c}\text { Cambridge } \\
\text { International } \\
\text { Dictionary of Idioms }\end{array}$ \\
\hline $\begin{array}{l}\text { free (simple) phrase/ } \\
\text { sentence }\end{array}$ & $27 \%$ & $18 \%$ & $23 \%$ & $23 \%$ \\
\hline $\begin{array}{l}\text { expended } \\
\text { (compound and } \\
\text { complex) sentence }\end{array}$ & $46 \%$ & $74 \%$ & $49 \%$ & $55 \%$ \\
\hline lexical unit & $18 \%$ & $3 \%$ & $15 \%$ & - \\
\hline cross-references & $9 \%$ & $5 \%$ & $13 \%$ & \\
\hline $\begin{array}{l}\text { a combined type of } \\
\text { definition }\end{array}$ & - & - & - & $22 \%$ \\
\hline
\end{tabular}


in the Cambridge International Dictionary of Idioms. The part explains what the idiom usually describes, when it can be used, shows the most typical range of objects or subjects for an idiom. For instance:

\section{once upon a time literary}

1 a long time ago \& This phrase is often used as a way of beginning children's stories. - Once upon a time there lived a young girl called Cinderella.

(CIDI, 2005, 394)

Secondly, most of the definitions used to describe complex idioms have a similar structure with prop words of these idioms in both the British and American dictionaries. For instance, $A d j+N, N+$ sentence structure are the most commonly used descriptive structures for the nominal idioms in the American dictionaries of idioms, whereas in contrast, $\operatorname{Adj}+\mathrm{N}$, $\mathrm{N}+$ Participle, $\mathrm{N}+$ sentence structure, indirect description are typical for the same nominal idioms in the British dictionaries. Interpretation of verb idiomatic phrases is by way of verbal combinations with the verb in the preposition. However, to interpret a verb idiomatic phrase, an indirect description is also used in the Cambridge International Dictionary of Idioms. For example:

\section{get the shaft American, informal}

if someone gets the shaft, they are not treated in a fair way - The tax system is all wrong - the rich just get richer and it's the poor who get the shaft.

(Ibid, 343)

So, the principle of idiom semantization is about the same in all dictionaries investigated in the work. But at the same time, the British dictionaries involve more definitions having different descriptive structures than the American.
Now we will proceed to the connotative component of the dictionaries. As already mentioned above, a label is such a component. Studying dictionaries we can say about the following categories of labels (see table 2)

According to the table, it is clear that emotive and expressive labels are not used at all in the phrase-books, whereas in contrast, functional and stylistic labels presents very limited, especially in the American dictionaries.

With regard to additional component of an entry, all dictionaries which are under review contain illustrative examples. In the Cambridge International Dictionary of Idioms, the Dictionary of American Idioms, entry heads are illustrated with examples based on sentences from different Corpuses. In the Oxford Dictionary of Idioms illustrative quotations are taken from a variety of sources: from novels to travel guides broadsheet newspapers to teenage magazines. The American Heritage Dictionary of Idioms uses quotations of earlier writers such as Chaucer. To avoid the difficulties in the process of reading, many quotations have had their spelling normalized and some have been rendered into Modern English. Thus, except The American Heritage Dictionary of Idioms all others contain examples that reflect natural written and spoken English.

In both the British and American dictionaries multiple meanings can be found in a number of idioms, but in different ways. Some idioms appear in both figurative and literal senses in the same entry in the Dictionary of American Idioms. One sense helps the user understand the other sense. In this case, the figurative sense has its origin in the literal sense. In the entries where this occurs, the literal senses are marked Lit. and the figurative senses are marked Fig. In The American Heritage Dictionary of Idioms the idiom meanings have a chronological order. For example: 
Table 2

\begin{tabular}{|c|c|c|c|c|}
\hline Categories of labels & $\begin{array}{l}\text { Dictionary } \\
\text { of American } \\
\text { Idioms }\end{array}$ & $\begin{array}{c}\text { The } \\
\text { American } \\
\text { Heritage } \\
\text { Dictionary } \\
\text { of Idioms }\end{array}$ & $\begin{array}{l}\text { Oxford } \\
\text { Dictionary } \\
\text { of Idioms }\end{array}$ & $\begin{array}{l}\text { Cambridge } \\
\text { International } \\
\text { Dictionary } \\
\text { of Idioms }\end{array}$ \\
\hline labels pointing at a certain communicative area & $\mathrm{v}$ & V & & V \\
\hline status labels & & & $\mathrm{v}$ & $\mathrm{V}$ \\
\hline temporal labels & & & & V \\
\hline \multicolumn{5}{|l|}{$\begin{array}{l}\text { labels pointing at a certain field of human action } \\
\text { or science }\end{array}$} \\
\hline labels pointing at a certain social sphere & & $\mathrm{V}$ & & V \\
\hline regional labels & & & $\mathrm{V}$ & $\begin{array}{l}\mathrm{V} \\
\end{array}$ \\
\hline $\begin{array}{l}\text { labels pointing at the area in which an idiom has } \\
\text { been used primarily }\end{array}$ & 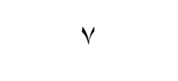 & & & \\
\hline emotive and expressive labels & & & & \\
\hline
\end{tabular}

\section{big daddy}

1. An influential man, a big shot (see under BIG CHEESE), as in You'll have to get permission from big daddy. [Slang; mid-1900s] 2. A male sweetheart or friend, often a man considerably older than his female companion; a SUGAR DADDY. [Slang; mid-1900s] 3. Grandfather. This usage originated in the South among African-Americans. 4. The largest or most important person or thing of its kind. For example, The United States has long been the big daddy of the Western Hemisphere, or The blue whale was the big daddy of the acean. [Slang; 1960s]

(AHDI, 2003: 99)

The British dictionaries list the meanings of idioms without any limitations. In these dictionaries, we find cases when the shadings of the same meaning are presented as an individual meaning. For example:

\section{without fail \\ 1 If something happens without fail, it always happens - Every Tuesday afternoon, without fail, Heiga went to visit her father. \\ 2 something that you say in order to emphasize that something will be done or will happen - 'You will meet me at the atrport, won't you?" "Don't worry, $T$ "ll be there without fail.'}

(CIDI, 2002, 125)

The example demonstrates a significant degree of subjectivity in establishing polysemy of idioms. In our opinion, to distinguish the meanings of the idiom "without fail" is difficult enough.

Another additional component of an entry which according to R.A. Ayupova we should pay attention is variance of FPs. In spite of containing American, British, Australian versions of idioms, the studied dictionaries do not inform about graphical variance of idioms. Only the Cambridge International Dictionary of Idioms contains data concerning grammatical forms of some components of idioms, for instance:

He/SherThey can whistle for it! (CIDI, 2002, 422);

take a/its/their toll (Ibid, 396);

as if there was/were no tomorrow (ibid).

Lexical (a tall story ttale (Ibid, 383),

burn to a cinder Also, burn to a crisp. (AHDI, 
2003, 147), balance the accounts 1. Lit. and balance the books (DAI, 2005, 32), spare (or save) someone's blushes

(ODI,

$2004,31)$ and in a less degree morphological (pass the hat around/round (CIDI, 2002, 79), bullshit artist Also, bull artist. (AHDI, 2003, 143)) variants of idioms are presented in the British and American dictionaries under consideration.

Various additional words are used optionally within a single idiomatic expression in Dictionary of American Idioms and Cambridge International Dictionary of Idioms. These words are included as a part of some idioms since they are so typical of conventional usage. Moreover, idiomatic expressions seem difficult simply because they are shortened versions of a longer expression that would be easier to understand in its full form. The following examples illustrate optional words:

The dictionaries do not record combinations, word lists with which an idiom can be used. Partly the data can be taken from examples provided in entries. The situation concerning the references to the grammatical valency of idioms is more favorably in the dictionaries. Each dictionary involves so-called wild card terms. As a rule, they are represented by someone, something, one's. All of the wild card terms are descriptive of the kind of words or phrases they can stand for. Wild card terms are mostly nouns, pronouns, and noun phrases. There is no way that these terms could be listed in an index. Therefore, the user is advised to save time by first looking up a verb, adverb, or preposition rather than a noun or pronoun. The Dictionary of American Idioms contains marks pointing at the definite grammatical features of components of idioms. The entry head, for instance break something down ${ }^{\dagger}$ (DAI, 2005, $60)$, contains a dagger $(\dagger)$ that indicates that the "down" can be transported to a position just after the verb. Among others there is an asterisk $\left(^{*}\right)$. For example: *abreast of someone or something (Ibid, 2). It means that the expression can usually stand alone, at least in a casual conversation but it can be preceded by the appropriate verbs given within the entry:

\footnotetext{
*abreast of someone or something 1 . Lit. keeping even with someone or something. ( ${ }^{\star}$ Typically: be $\sim$; get $\sim$; keep $\sim$; stay $\sim$.) $\square$ I had to run hard to stay abreast of Sally. 2. Fig. knowing the news about someone or something. ( ${ }^{\star}$ Typically: be $\sim$; get $\sim$; keep $\sim$; stay $\sim$.) $\square$ The press corps has to keep abreast of the president.
}

Some grammatical features are labeled at examples in the Cambridge International Dictionary of Idioms. For instance:

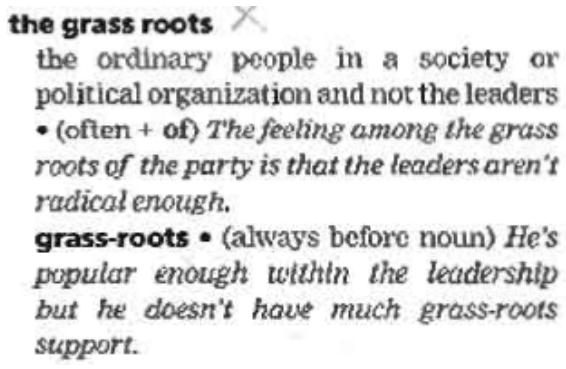

(CIDI, 2002, 162), i.e.the dictionary denotes that this idiom is often followed by the preposition "of", and "grass-roots" as an adjective is always used before the noun it describes.

or

\section{grin like a Cheshire cat • (usually im continuous tenses) What hove you got to look so frappy about, walking round here grinsting like a Cheshive cat?}

(Ibid, 164), i.e. this idiom is usually used in continuous tenses.

The Oxford Dictionary of Idioms and the American Heritage Dictionary of Idioms make a retrospective journey in the history of the origin of idioms as well as its use and its individual components. The Cambridge International Dictionary of Idioms gives comments on specific words which are in the combination of groups of idioms which all use the same figurative meaning of the words. In such cases, a note explains the figurative meaning and all idioms which follow it have that meaning. For instance: 
Blood is also used in the following phrases to refer to the connections that exist between members of the same famlly.

\section{Blood is thicker than water.}

something that you say which means family relatlonships are stronger and more important than other kinds of relationships, such as being friends - They say blood ts thicker than water, so how come so many fantilies hate each other?

\section{a blood brother}

a man who has promised to treat another man as his brother, often in a ceremony in which they cut thernselves and mix their blood together - We were blood brothers - I was ready to die for him.

(Ibid, 40) Also idioms which are very common and useful for learners of English are highlighted in the dictionary, for instance

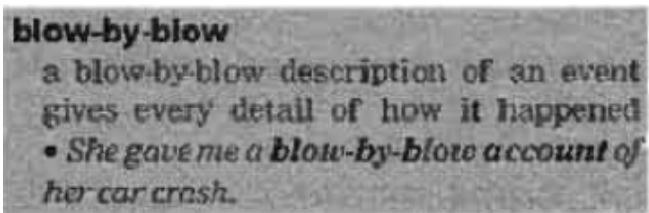

(Ibid) There are also photocopiable exercises at the back of the dictionary.

Thus, the American Heritage Dictionary of Idioms, the Oxford Dictionary of Idioms and the Cambridge International Dictionary of Idioms involving historical, culturological data gives opportunity to have vast information about the idiom of interest. In addition to the principle of prescription, the principle of training and methodological practicability is added in the Dictionary of American Idioms and the Cambridge International Dictionary of Idioms. Their entries are aimed not only to explain and show how to use idioms, but also to help those who are learning the English language.

\section{Conclusion}

The comparative analysis of significative and denotative, connotative and additional components of an entry showed the following features the American and British dictionaries of idioms:

- deficiencyofBritish-American,American or British common lexicographic standards of idiom description. As a result, we were observing a spontaneous, inconsistence and, in common, nonsystemic choice, interpretation and presentation of idioms;

- lack of structural and linguistic date, namely, information about semantic relations, lexical valency and syntagmatic relationship the studied idioms to appreciate better their meanings and use easier in discourse in both the American and British dictionaries;

- existence the tendency to make a full, manifold, polyfunctional characteristics of a lexical item in both American and British lexicographic practice;

- constructiveness the trend to make dictionary integral part of the didactic material for studying English in both lexicographic practice

\section{References}

Ayupova, R.A. Problemyi leksikograficheskogo opisaniya frazeologicheskih edinits (na materiale angliyskogo, russkogo i tatarskogo yazyikov): avtoref. dis. doktora filol. nauk [Towards lexicographic description of fixed phrases (based on dictionaries of the English, Russian and Tartarian languages)]. Kazan', 2009, 44 p.

Baranov, A.N., Dobrovolskii, D.O. (1998). Idiom's inner form and the problem of interpretation. Izvestiia RAN, 1, 36-44. 
Bashieva, S.K. Stilisticheskii komponent frazeologicheskogo znacheniia. Dis. d-ra filol. nauk [A stylistic component of phraseological meaning: Thesis]. Nalchik, 1998, 318 p.

Cambridge International Dictionary of Idioms. Cambridge, Cambridge University press, 2003, $497 \mathrm{p}$.

Chornobay, S.Y. (2011). The definition of idiom in modern phraseology. Uchenyie zapiski Tavricheskogo natsionalnogo universiteta im. V.I. Vernadskogo, 2011, 24(63), No 3, available at: http:// science.crimea.edu/zapiski/2011/filologiya/uch24_3fn/054.pdf

Dictionary of American Idioms. R.A. Spears (ed). New-York, McGraw-Hill, 2005, 1080 p.

Ermolaeva, Yu.A. Printsipyi leksikograficheskogo opisaniya russkoy frazeologii (na materiale slovarnyih statey obschih $i$ uchebnyih slovarey). Avtoref. dis. kand. filol. nauk [The principles of lexicographic description in Russian phraseology (based on entries of general and learner's dictionaries)]. Leningrad, 1990, $17 \mathrm{p}$.

Grant, L., Bauer, L. (2004) Criteria for Re-defining Idioms: Are we Barking up the Wrong tree? Applied Linguistics, 25(1), 38-61.

Kunin, A.V. Kurs frazeologii sovremennogo angliiskogo iazyka [Lectures on phraseology of the English language]. Moscow, Vysshaia shkola, 1996, 380 p.

L'vov, M.P. Osnovy teorii rechi: Uchebnoe posobie dlia pedinstitutov [Elements of speech theory: Study guide for teacher's institutes]. Moscow, Voskhod, 2000, 245 p.

Makkei, A. Idiom structure in English. Paris, 1972, 243 p.

Minaeva, L.V. Slovo v iazyke i rechi: Uchebnoe posobie [Word in language and speech: Study guide]. Moscow, Nauka, 1986, 145 p.

Moon, R. Fixed expressions and idioms in English. A corpus-based approach. Oxford, Claderon Press, 1998, 338 p.

Oxford Dictionary of Idioms. J. Siefring (ed). Oxford, Oxford University press, 2004, 340p.

Sternin, I.A., Chiubur, T.A. The principles of word description in contrastive defining-interlingual dictionaries. Kontrastivnaia leksikologiia i leksikografiia, Voronezh, Istoki, 2006, pp. 136-159.

Sternin I.A. Speech nomination and lexical meaning variation of word. Problemy semantiki russkogo iazyka. Yaroslavl, Kniga, 1986, pp. 3-13.

Stupin L.P. Leksikografia angliiskogo iazyka: Uchebnoe posobie [English lexicography: Study guide]. Moscow, Vysshaia shkola, 1985, 168 p.

Teliya, V.N. Russkaya frazeologiia. Semanticheskii, pragmaticheskii i kulturologicheskii aspekty [Russian phraseography. Semantic, pragmatic and culturological aspects]. Moscow, Nauka, 1996, $284 \mathrm{p}$.

The American Heritage Dictionary of Idioms. Ch. Ammer (ed). Boston, Houghton Mifflin Company, 2003, $497 \mathrm{p}$.

Zhorzholiani, D.A. Teoreticheskie osnovy frazeologicheskoi nominacii i sopostavitel'naia lingvistika: Uchebnoe posobie dlia pedinstitutov [Theoretical foundations of phraseological nomination and comparative linguistics: Study guide for teacher's institutes]. Moscow, Vysshaia shkola, 1987, $191 \mathrm{p}$. 


\section{К проблеме лексикографического описания идиом \\ в английском языке: \\ сравнительный анализ}

Ю.С. Перевезенцева

Нижегородский государственньй технический университет им. Р.Е. Алексеева Россия, 603950, Нижний Новгород, Минина, 24

В статье сравниваются две практики лексикографического описания идиом: британская и американская. В центре внимания оказываются современные и наиболее авторитетные американские и британские словари идиом. Предметом изучения является словарная статья, а объектом - её сигнификативно-денотативные, коннотативные и дополнительные компоненты. Проведенное исследование выявляет достоинства, недостатки и перспективы сравниваемых лексикографических практик.

Ключевые слова: идиома, словарь, лексикографическое описание, британские и американские словари идиом.

Научная спещиальность: 13.00.00 - педагогические науки, 10.00.00 - филологические науки. 